\title{
Some features of one-year-old tart Cherry shoots of cv. Schattenmorelle
}

\author{
DARIUSZ S'WIETLIK*, KAZIMIERZ SLOWIK and STEFAN REJMAN \\ Institute of Pomology and Floriculture, \\ 96-100 Skierniewice, Poland
}

(Received: June 1, 1987)

\begin{abstract}
The purpose of this study was to obtain data on the relationship between the length of 1 -year-old shoots and their fruiting, and both their terminal and lateral growtn produced in the current year. The measurements were taken in 1977 and 1979 from the tart cherry trees of cv. Schattenmorelle grafted of Prunus mahaleb L. or Prunus avium L. grown in loose sandy soil. In 1977 there were more shoots of over $30 \mathrm{~cm}$ than in 1979 . The longer the shoots, the more lateral shoots were there. Only the shortest shoots $(1-10 \mathrm{~cm})$ bore more fruit per unit length as compared to the longer shoots.
\end{abstract}

\section{INTRODUCTION}

Schattenmorelle is the most widely planted tart cherry cultivar in Poland. Out of all the tart cherry cultivars in use in the country, it is the most important due to its fruiting capacity and its exellent processing value.

Generative (flower) buds are formed mainly at the base of the leaves on the current year shoots (spurs are very rare). Fruits orginate from these buds the following year. Alternatively, a vegetative (leaf) bud may be induced which produces a lateral shoot in the following season. The bud formed on the top of the current year shoot is almost always a vegetative one. As the tree becomes older, generative buds can prevail on its shoots and hence only a few laterals are formed in the next season. Within a few years this results in bare and droopy branches and causes a drastic reduction of the cherry crop.

The purpose of this study was to obtain information on the relationship between the length of an individual 1-year-old shoot (formed in the previous year) and its fruiting, and both its terminal and lateral (if present) growth produced in the current year.

* Presently at Texas A and I University, Citrus Center Weslaco, USA. 


\section{MATERIALS AND METHODS}

The measurements were taken in 1977 and 1979 from the tart cherry trees of cv. Schattenmorelle grafted on Prunus mahaleb L. or Prunus avium L. rootstocks, at the Experimental Station of the Research Institute of Pomology and Floriculture in Strobow near Skierniewice (central Poland). The trees were planted in the autumn of 1972 on loose sandy soil. Twenty two of the trees that were grafted on Prunus mahaleb $\mathbf{L}$. and twenty three of those grafted on Prunus avium L. were selected for the study. The average values of the features characterizing growth and fruiting of the selected tart cherry trees and their corresponding variation coefficient values $(\mathrm{V} \%)$ are given in Table 1.

\section{Table 1}

The average values $(\bar{x})$ of the features characterizing growth and fruiting of the selected tart cherry cv. Schattenmorelle and their corresponding variation coefficient values $(V \%)-1977$

\begin{tabular}{|c|c|c|c|c|}
\hline \multirow{3}{*}{ Feature } & \multicolumn{4}{|c|}{ Rootstocks } \\
\hline & \multicolumn{2}{|c|}{$\begin{array}{c}\text { Prunus mahaleb L. } \\
n=22 \text { trees }\end{array}$} & \multicolumn{2}{|c|}{$\begin{array}{l}\text { Prunus avium L. } \\
n=23 \text { trees }\end{array}$} \\
\hline & $\bar{x}$ & $V \%$ & $\bar{x}$ & $V \%$ \\
\hline Total length of the 1-year-old shoots (cm) & 6261 & 25.9 & 5302 & 27.2 \\
\hline Total number of the 1-year-old shoots & 279 & 25.8 & 224 & 25.3 \\
\hline $\begin{array}{l}\text { Total number of the 1-year-old shoots } \\
\text { which produced laterals }\end{array}$ & 25 & 53.8 & 21 & 68.1 \\
\hline $\begin{array}{l}\text { Total length of the current year shoots } \\
\text { (cm) }\end{array}$ & 8090 & 27.3 & 6741 & 31.5 \\
\hline $\begin{array}{l}\text { Total length of the current year terminal } \\
\text { shoots (cm) }\end{array}$ & 6522 & 28.3 & 5499 & 29.7 \\
\hline $\begin{array}{l}\text { Total length of the current year lateral } \\
\text { shoots }(\mathrm{cm})\end{array}$ & 1568 & 55.6 & 1243 & 84.5 \\
\hline Yield $(\mathrm{kg} /$ tree $)$ & 9.97 & 36.5 & 7.03 & 37.6 \\
\hline
\end{tabular}

In 1979 eight tart cherry trees grafted on Prunus mahaleb L. were selected from those used for the study in 1977. In both years the measurements were taken just before harvest (the beginning of August).

The length of every 1-year-old shoot (shoot formed in the previous year) on each tree was measured. The number of fruit and current year lateral shoots (if present) on each 1-year-old shoot was recorded. Also the length of elongation (terminal) growth of each 1-year-old shoot was measured. The 1-year-old shoots were divided into 4 groups $(1-10,11-20,21-30,>30 \mathrm{~cm})$ according to their length.

The analysis of variance was carried out using the values of the following 
parameters length of terminal growth of the 1-year-old shoot, percent of the 1-year-old shoots with current year laterals, the number of fruits per $10 \mathrm{~cm}$ of the 1-year-old shoot and the number of fruits per single 1-year-old shoot.

\section{RESULTS}

In the case of tart cherry trees grafted on Prunus mahaleb L. and Prunus avium L. about 21 nad $16 \%$ of the 1-year-old shoots having lengths above 30 $\mathrm{cm}$ produced lateral shoots, respectively (Table 2). A much lower percentage of the shoots having lengths below $30 \mathrm{~cm}$ gave lateral shoots - particularly those whose length did not exceed $10 \mathrm{~cm}$.

\section{Table 2}

Percentage of the 1-year-old tart cherry shoots which produced laterals (1977)

\begin{tabular}{ccc}
\hline \multirow{2}{*}{$\begin{array}{c}\text { Length of } \\
\text { shoots (cm) }\end{array}$} & \multicolumn{2}{c}{ Rootstocks } \\
\cline { 2 - 3 } & Prunus mahaleb L. & Prunus avium L. \\
\hline $1-10$ & $1.54 \mathrm{a}^{2}$ & $3.67 \mathrm{a}$ \\
$11-20$ & $4.44 \mathrm{~b}$ & $4.93 \mathrm{a}$ \\
$21-30$ & $5.19 \mathrm{~b}$ & $5.90 \mathrm{a}$ \\
$>30$ & $20.85 \mathrm{c}$ & $15.94 \mathrm{~b}$ \\
\hline
\end{tabular}

${ }^{x}$ Mean separation in columns differs significantly at the $5 \%$ level according to Duncan's Multiple Range Test.

It was found that the longer the 1-year-old shoot, the longer its terminal growth (Table 3).

The shortest shoots $(1-10 \mathrm{~cm})$ bore more fruit per unit of their length compared to the longer shoots (Table 4). No differences were observed in the density of fruit born on 1-year-old shoots belonging to the other three groups of shoots: 11-20, 21-30, > $30 \mathrm{~cm}$ (Table 4).

Table 3

Terminal growth (cm) of 1-year-old tart cherry shoots (1977)

\begin{tabular}{ccc}
\hline \multirow{2}{*}{$\begin{array}{c}\text { Length of } \\
\text { shoots }(\mathrm{cm})\end{array}$} & \multicolumn{2}{c}{ Rootstocks } \\
\cline { 2 - 3 } & Prunus mahaleb L. & Prunus avium L. \\
\hline $1-10$ & $23.34 \mathrm{a}^{\mathrm{z}}$ & $25.51 \mathrm{a}$ \\
$11-20$ & $22.91 \mathrm{a}$ & $24.31 \mathrm{a}$ \\
$21-30$ & $26.17 \mathrm{~b}$ & $27.11 \mathrm{~b}$ \\
$>30$ & $30.19 \mathrm{c}$ & $30.22 \mathrm{c}$ \\
\hline
\end{tabular}

See Table 2 
Table 4

Number of tart cherry fruit born per $10 \mathrm{~cm}$ of 1-year-old shoots

(1977)

\begin{tabular}{ccc}
\hline \multirow{2}{*}{$\begin{array}{c}\text { Length of } \\
\text { shoots (cm) }\end{array}$} & \multicolumn{2}{c}{ Rootstocks } \\
\cline { 2 - 3 } & Prunus mahaleb L. & Prunus avium L. \\
\hline $1-10$ & $6.61 \mathrm{~b}^{\mathbf{z}}$ & $5.90 \mathrm{~b}$ \\
$11-20$ & $3.77 \mathrm{a}$ & $3.39 \mathrm{a}$ \\
$21-30$ & $3.92 \mathrm{a}$ & $3.40 \mathrm{a}$ \\
$>30$ & $3.70 \mathrm{a}$ & $3.48 \mathrm{a}$ \\
\hline
\end{tabular}

See Table 2.

When the fruiting of the 1-year-old shoots was expressed as the number of fruits per single shoot, it appeared that longer shoots bore more fruits than shorter ones (Table 5).

Table 5

Number of the tart cherry fruit born per single 1-year-old shoots (1977)

\begin{tabular}{ccc}
\hline \multirow{2}{*}{$\begin{array}{c}\text { Length of } \\
\text { shoots (cm) }\end{array}$} & \multicolumn{2}{c}{ Rootstocks } \\
\cline { 2 - 3 } & Prunus mahaleb L. & Prunus avium L. \\
\hline $1-10$ & $3.15 \mathrm{a}^{\mathrm{z}}$ & $2.80 \mathrm{a}$ \\
$11-20$ & $6.05 \mathrm{~b}$ & $5.38 \mathrm{~b}$ \\
$21-30$ & $9.98 \mathrm{c}$ & $8.73 \mathrm{c}$ \\
$>30$ & $13.91 \mathrm{~d}$ & $12.94 \mathrm{~d}$ \\
\hline
\end{tabular}

See Table 2.

In 1979 the tart cherry trees were much bigger but also less vigorous. There was a very low number of shoots exceeding the length of $30 \mathrm{~cm}$. Due to this, the group of shoots $>30 \mathrm{~cm}$ in length was not separated.

In Table 6 the percentage of the 1-year-old shoots which produced lateral shoots is given. A negligible portion of the shoots in the first two groups produced lateral shoots but almost $5 \%$ of the shoots $>20 \mathrm{~cm}$ in length produced them.

As in 1977, the long 1-year-old shoots produced more terminal growth than the short ones (Table 7), although the current year terminals in 1979 were much weaker than in 1977 (Table 7).

In contrast with the results obtained in 1977 , there was no large difference 
in the density of fruit born on the shoots of different lengths (Table 8), but again it was clearly visible that the longer the 1-year-old shoot, the higher the amount of fruit it produced (Table 8).

Table 6

Percentage of the 1-year-old tart cherry shoots which produced laterais (1979)

\begin{tabular}{cc}
\hline $\begin{array}{c}\text { Length of } \\
\text { shoots }(\mathrm{cm})\end{array}$ & $\begin{array}{c}\text { cv. Schattenmorelle } \\
\text { Prunus mahaleb L. }\end{array}$ \\
\hline $1-10$ & $0.27 \mathrm{a}^{\mathrm{z}}$ \\
$11-20$ & $0.68 \mathrm{a}$ \\
$>20$ & $4.67 \mathrm{~b}$ \\
\hline
\end{tabular}

See Table 2

\section{Table 7}

Terminal growth $(\mathrm{cm})$ of the 1-year-old tart cherry shoots (1979)

\begin{tabular}{cc}
\hline $\begin{array}{c}\text { Length of } \\
\text { shoots }(\mathrm{cm})\end{array}$ & $\begin{array}{c}\text { cv. Schattenmorelle } \\
\text { Prunus mahaleb L. }\end{array}$ \\
\hline $1-10$ & $7.89 \mathrm{a}^{\mathrm{z}}$ \\
$11-20$ & $11.38 \mathrm{~b}$ \\
$>20$ & $16.39 \mathrm{c}$ \\
\hline
\end{tabular}

See Table 2.

Table 8

Number tart cherry fruits born per $10 \mathrm{~cm}$ of the 1-year-old shoot and per single 1-year-old shoot (1979)

\begin{tabular}{ccc}
\hline \multirow{2}{*}{$\begin{array}{c}\text { Length of } \\
\text { shoots }(\mathrm{cm})\end{array}$} & \multicolumn{2}{c}{ cv. Schattenmorelle(Prunus mahaleb L.) } \\
\cline { 2 - 3 } & $\begin{array}{c}\text { No. of fruit per } \\
10 \mathrm{~cm} \text { of shoot }\end{array}$ & $\begin{array}{c}\text { No. of fruit per } \\
\text { single shoot }\end{array}$ \\
\hline $1-10$ & $3.86 \mathrm{~b}^{\mathrm{z}}$ & $2.21 \mathrm{a}$ \\
$11-20$ & $3.27 \mathrm{a}$ & $5.06 \mathrm{~b}$ \\
$>20$ & $3.24 \mathrm{a}$ & $7.54 \mathrm{c}$ \\
\hline
\end{tabular}

see Table 2.

\section{DISCUSSION}

The results presented above indicate very clearly that there is a very strong relationship between the length of individual 1-year-old shoots and their elongation growth, in respect to their ability to produce lateral shoots. A considerable percentage (approximately $20 \%$ ) of the 1-year-old shoots over $30 \mathrm{~cm}$ in length produced laterals while a very small part of the shoots $<30 \mathrm{~cm}$ in length did so (Tables 2 and 6). In addition, the terminal growth of the longer 1 -year-old shoots was more vigorous (Tables 3 and 7). Thus, the longest 1-year-old shoots $(>30 \mathrm{~cm}$ ) were able to produce a larger bearing surface for the next season than the shorter ones $(<30 \mathrm{~cm})$, especially those which did not exceed $10 \mathrm{~cm}$. The production of lateral shoots is very important because it prevents the formation of droopy, barren branches which are unproductive. Kenworthy (1974) reported that in the case of cv. Montmorency tart cherry 
trees the optimal length of the shoot varies between $25-40 \mathrm{~cm}$. On such shoots an appropriate ratio between generative and vegetative buds is maintained providing good fruiting and production of lateral shoots and spurs in the next season.

Parker et al. (1964) reported that tart cherry trees of cv. Montmorency infected with virus yellows are less vigorous and produce an excess of generative buds on the shoots. This results in a reduced number of spurs and lateral shoots and after some period of time in a reduction of the crop. Gibberellic acid treatment on yellows-infected trees increased the number of vegetative buds on the shoots and improved the spur system and yield.

The main feature of the shortest shoots $(1-10 \mathrm{~cm})$ was the high density of fruit borne on them (Table 4). It can be expected that the formation of many such shoots may temporarily increase the yield followed by a considerable reduction in the crop in the next few years as a result of a decreased bearing surface of the tree. It should be stressed that there was no difference in the density of the fruit born on the 1-year-old shoots from the groups 11-20, 21-30 and $>30 \mathrm{~cm}$ (Table 4).

Because the length of internodes always increases with the increasing length of the shoot, it can be speculated that a single generative bud on the longer shoots produced more flowers and/or there was better fruit set on the longer shoots.

Thus it can be suggested that in order to maintain high fruiting capacity of tart cherry trees of cv. Schattenmorelle the new growth should exceed $>30 \mathrm{~cm}$. From the results presented above the upper limit of shoot growth cannot be determined, although it should be kept in mind that excessive growth can result, as was shown by Kenworthy (1974), in an excess of vegetative buds. Such a situation is rather typical for young tart cherry trees.

\section{REFERENCES}

Kenworthy A. L., 1974. Sour cherry-tree vigours as related to higher yields and better fruit quality. Agric. Expt. Sta., East Lansing Res. Report No. 223.

Parker K. G., Edgerton L. Y., Hickey K. D., 1969. Gibberellin treatment for yellows-infected sour cherry trees. Farm Research, 29.

Niektóre cechy jednorocznych pędów wiśni odmiany Łutówka

\section{Streszczenie}

Celem badań bylo uzyskanie danych dotyczących współzależności pomiędzy długością jednorocznych pędów a ich zdolnością owocowania oraz pomiędzy długością pędów w danym roku a wytwarzaniem rozgałęzien na tych pędach. Pomiary przeprowadzono w Sadowniczym 
Zakładzie Doświadczalnym Instytutu Sadownictwa i Kwiaciarstwa w gospodarstwie Strobów. Wykonywano je tuż przed zbiorem owoców w 1977 i 1979 na wiśniach odmiany Lutówka uszlachetnionych na Prunus mahaleb L. oraz Prunus avium L. Drzewa posadzone były jesienią 1972 r. na piasku luźnym. W roku 1977 stwierdzono więcej pędów o długości powyżej $30 \mathrm{~cm}$ niż w roku 1979. Im dłuższe były pędy, tym więcej $z$ nich dawało rozgałęzienia boczne. Tylko najkrótsze pędy $(1-10 \mathrm{~cm})$ dawały więcej owoców na jednostkę długości w porównaniu do dłuższych pędów. Prowadzi to w miarę upływu czasu do zmniejszenia powierzchni owoconośnej. 